Hispania Sacra, LXII

125, enero-junio 2010, 93-113, ISSN: 0018-215-X

\title{
AS MANIFESTAÇÕES DE RUA DAS MISERICÓRDIAS PORTUGUESAS EM CONTEXTO BARROCO
}

\author{
POR \\ María Marta Lobo de AraúJo \\ Docente do departamento de História, Universidade do Minho-Portugal
}

\section{RESUM}

O nosso trabalho analisa algumas das manifestações públicas das Misericórdias portuguesas em contexto barroco, procurando destacar os aspectos mais relevantes desses momentos. Grandiosidade, esplendor, brilho e caridade eram alguns dos ingredientes que se associavam nessas ocasiões, com o objectivo de publicitar os seus rituais de caridade e simultaneamente dar visibilidade ao poder dos que compunham estas instituições. Gestos preparados com minúcia, cerimónias que se desejavam inegualáveis e comportamentos que se esperavam adequados eram mecanismos que as Misericórdias accionavam quando se agigantavam nestas manifestações públicas de rua.

PALAVRAS-CHAVE: Misericórdias, procissões, barroco, caridade.

\section{LAS MANIFESTACIONES DE LA CALLE DE LAS MISERICÓRDIAS PORTUGUESAS EN EL CONTEXTO BARROCO}

\section{RESUMEN}

Nuestro trabajo analiza algunas de las manifestaciones públicas de las Misericordias portuguesas en el contexto barroco, destacando los aspectos más relevantes de aquellos tiempos. Grandiosidad, esplendor, brillo y caridad eran algunos de los ingredientes que se asociaban a aquellas ocasiones, con el objetivo de publicitar los rituales de caridad y, simultaneamente, dar visibilidad al poder de aquellos que dirigían estas instituciones. Gestos preparados con meticulosidad, ceremonias que pretendían ser inigualables y comportamientos que se 
esperaban adecuados, eran mecanismos que las Misericordias desplegaban cuando estas manifestaciones públicas salían a las calles.

PALABRAS CLAVE: Misericordias, procesiones, barroco, caridad.

\title{
THE STREET DEMONSTRATIONS OF PORTUGUESE MISERICÓRDIAS WITHIN THE BAROQUE CONTEXT
}

\begin{abstract}
This paper analyses some of the public demonstrations of the Portuguese Misericórdias within the baroque context, highlighting some of the most relevant aspects of those moments. Magnificence, splendour, pomp and charity were some of the ingredients that would be associated in these occasions, under the goal of publicizing their charity rituals and, simultaneously grant visibility to the power of those who were members of these institutions. Gestures, prepared to the detail, ceremonies that were designed to be unique and behaviours that were expected to be adequate, such were the mechanisms that the Misericórdias activated whenever they would elevate themselves in these public street demonstrations.
\end{abstract}

KEY WORDS: Misericórdias, processions, baroque, charity

Recibido/Received 25-11-2008

Aceptado/Accepted 19-12-2009

\section{INTRODUÇÃO}

Analisar o enquadramento barroco em que actuavam as Misericórdias portuguesas sempre que saíam à rua é estudar os seus actos públicos durante os séculos XVII e XVIII.

Confrarias muito prestigiadas onde actuavam as elites locais, as Santas Casas foram responsáveis pela realização de cerimónias públicas, bem como participaram em variados desfiles processionais, promovidas por outras confrarias, cabidos, sés, colegiadas, igrejas paroquiais, etc.

A primeira Misericórdia portuguesa nasceu em Lisboa, em 1498, num enquadramento de renovação religiosa. Rapidamente estas confrarias se disseminaram por todo o reino e império, demonstrando a adesão das elites locais. Eram compostas apenas por homens nobres e oficiais, cumpriam as 14 obras de misericórdia, operavam com numerus clausus e transformaram-se nas irmandades mais prestigiadas das localidades em que estavam inseridas.

A sua função prioritária era a caridade, mas deram origem a muitas outras manifestações.

No desempenho das obras de misericórdia, as Santas Casas envolveram-se em actos solenes, patrocinados pelas próprias ou por benfeitores que lhes in- 
cumbiram essa responsabilidade. Algumas cerimónias, muitas vezes com carácter perpétuo, deram lugar a rituais de caridade, onde actuavam não apenas os irmãos da confraria, mas também os pobres e os que presenciavam estas manifestações.

Analisamos em primeiro lugar as cerimónias promovidas pelas Misericórdias, dando posteriormente realce às restantes em que eram intervenientes.

\section{AS MANIFESTAÇÕES DE RUA: OS ENTERROS}

Sabendo da importância que tinham os momentos em que saíam à rua, as Misericórdias cuidavam em particular destas ocasiões, dando relevo à sua imagem, bem como aos que se envolviam na sua realização. ${ }^{1}$

Sempre que saíam em corpo ou com alguns dos seus elementos, preparavam minuciosamente o momento, tratando de tudo com antecedência, porque os olhares eram muitos, os juízos variados e as Santas Casas não queriam ser mal avaliadas. Numa época em que ver, ouvir e sentir eram factores com muito peso, estas instituições esmeravam-se para que a sua imagem pública não desmerecesse.

Embora confrarias de leigos, que actuavam sob a imediata protecção régia, estatuto que alcançaram no Concílio de Trento, as Misericórdias tinham uma intensa ligação com a igreja católica, desde logo pela necessidade de dar cumprimento à sétima obra de misericórdia corporal. Enterrar os mortos foi uma função cumprida desde o início e que as obrigou a interagir com outros agentes locais.

O compromisso ${ }^{2}$ da Misericórdia de Lisboa de $1516^{3}$ dava atenção apenas aos enterros dos irmãos e assim será até 1618. Todavia, desde sempre as Santas Casas enterraram membros e pessoas comuns.

Desde 1593 que a Misericórdia de Lisboa alcançou o privilégio de enterrar os mortos, benefício de que todas as congéneres se procuraram igualmente munir. Os privilégios eram adquiridos junto do monarca, desde que solicitados pelas Santas Casas.

Possuidoras de mobiliário fúnebre, de igrejas e sacristias apetrechadas, capelas, altares privilegiados e de um corpo de capelães, as Misericórdias, porque

\footnotetext{
1 Veja-se M. M. Lobo de AraúJo, Rituais de caridade na Misericórdia de Ponte de Lima (séculos XVII-XIX), Braga, Santa Casa da Misericórdia de Ponte de Lima, 2003, pp. 47-51.

2 Designação que significava estatutos.

${ }^{3}$ Os compromissos da Santa Casa de Lisboa eram enviados a todas as Misericórdias pelo rei, desde que pedidos.
} 
gozavam de muito prestígio local, transformaram-se em gestoras de fortunas, ${ }^{4}$ funcionando como seguradoras e intermediárias entre o legatário e o Além. 5

Para dignificar estes actos, as Misericórdias preparavam-se, efectuando compras sempre que podiam para rechear a sacristia e a igreja: compravam-se ornatos e adquiriam-se tumbas novas quando as existentes não estavam em condições. Forradas com panos de damasco, ou de veludo as tumbas dos irmãos eram guarnecidas a ouro e os panos dos melhores que se conseguiam comprar.

No compromisso de 1618 desapareceu o capítulo destinado aos enterros dos irmãos para dar lugar a um outro que abarcava todos os enterramentos.

Tratando-se de dar cumprimento a uma das principais obras de caridade, como o texto compromissal referia, o provedor e os mesários deviam esforçar-se para que estas cerimónias decorressem com «decencia e christandade, e com respeito às pessoas que falecerem». Como eram já recorrentes as faltas dos irmãos nestes momentos, bem como os escândalos provocados nestas ocasiões, o regimento apelava para que actuassem dentro das normas e com caridade cristã. A «decencia» com que o acto devia decorrer era também sublinhada.

Como se tratava de uma tarefa que os confrades tinham de desempenhar frequentemente e nem sempre a desejavam cumprir, os enterros tornaram-se em ocasião de atritos e rebentaram, em certos momentos, em escândalos públicos. As Misericórdias não toleravam estes desacatos, não apenas por serem fora de portas, mas sobretudo porque diminuíam o seu crédito. Por isso, reagiam em conformidade e, em muitos casos, depois das admoestações, o risco, ou seja, a expulsão foi o mais comum.

Os irmãos foram em muitas situações os principais actores do conflito: os confrades nobres recusavam-se a carregar o esquife nos enterros, não compareciam nestas cerimónias ou iam muitas vezes sem balandrau, num tom de desafio claro às normas da instituição que tinham jurado cumprir quando entraram. ${ }^{6}$

As cerimónias públicas em que as instituições se apresentavam em corpo foram frequentemente escolhidas para manifestações de desagrado, tendo-se veri-

\footnotetext{
${ }^{4}$ Veja-se M. F. CAstro, A Misericórdia de Braga. Assistência material e espiritual, Braga, Santa Casa da Misericórdia e Autora, 2006, pp. 293-608.

${ }^{5}$ Consulte-se para esta matéria P. Ariès, Sobre a História da Morte no Ocidente desde a Idade Média, Lisboa, Ed. Teorema, 1975, pp. 34-117.

${ }^{6} \mathrm{~A}$ propósito da cólera de alguns irmãos nestes momentos confira-se Â. BARRETO XAVIER; J. P. PAIVA, «Introdução», in J. P. PAIVA, Portugaliae Monumenta Misericordiarum, vol. 4, Lisboa, União das Misericórdias; Centro de Estudos de História Religiosa, 2005, p. 12; M. D. Sousa PereIRA, Entre ricos e pobres: a actuação da Misericórdia de Ponte da Barca (1630-1800), Braga, Universidade do Minho, 2003, pp. 68-78, dis. de mestrado policopiada; E. Lemos, A Santa Casa da Misericórdia da vila da Lousã - resenha histórica, Lousã, s. n., 1966, p. 111.
} 
ficado este comportamento não apenas nas Misericórdias, mas também em muitas outras instituições.

A conflitualidade marcou a Idade Moderna e sentiu-se particularmente no século XVIII, período em que as Santas Casas entraram em crise. Estas confrarias sentiam-se também penalizadas por estes actos, procurando erradicá-los com eficácia e na proporção da ofensa.

Para além da importância financeira, os enterros reuniam ainda outros benefícios para as Misericórdia. Eram sempre ocasiões de mostrar grandeza e capacidade de realização de tão importantes serviços. Uma vez mais as Misericórdias exibiam a sua acção abrangente, numa prestação que faziam aos pobres, aos irmãos e aos que desejassem ser acompanhados por si. ${ }^{7} \mathrm{O}$ diploma alcançado em 1593 foi fundamental para que estas confrarias adquirissem um carácter abrangente no campo dos enterros.

Nos funerais dos confrades, todos os irmãos desfilavam «postos em ordem», cabendo ao provedor encerrar o cortejo. Atrás dele seguia a tumba, carregada por seis confrades. ${ }^{8}$

Os enterros ocasionavam sempre desfiles. Uma parte da cerimónia era realizada dentro de portas, mas para levar o féretro à sepultura, caso esta não se realizasse dentro da igreja da confraria, era preciso sair à rua e percorrer o caminho necessário. No cortejo, integravam-se quase sempre outras confrarias, tantas quantas o defunto desejasse e pudesse pagar por este serviço, bandeiras, tochas e, por vezes, música, originando um desfile de cor, de brilho, de sons e de gente. Pessoas que participavam, mas que também assistiam, ajuizando a capacidade organizadora da instituição que promovia a cerimónia, mas igualmente os que a integravam. Dependendo da vontade do defunto, o desfile podia ainda integrar pobres, tantos quanto fosse a sua determinação. Levavam normalmente velas acesas, como o falecido tinha determinado.

A presença dos pobres nestes actos não é de menor importância e requer atenção. Para além de complementarem um acto cénico que os enterros proporcionavam, os pobres adquiriam um carácter simbólico de grande significado. Esperava-se que orassem em favor da alma do falecido e aguardava-se que mais facilmente fosse atendidos nas suas súplicas, por estarem mais perto de Deus. Era com este propósito que eram chamados para estes momentos.

\footnotetext{
${ }^{7}$ Os irmãos eram enterrados gratuitamente, bem como os pobres. Todos os restantes pagavam o funeral, de acordo com o tarifário praticado pela instituição. Leia-se M. A. NETo SALVADO, A Misericórdia de Medelim - apontamentos para a sua história, Castelo Branco, Câmara Municipal de Idanha - a Nova, 2002, pp. 27-33.

${ }^{8}$ Compromisso da Misericórdia de Lisboa, Lisboa, Pedro GAESBEECK, 1619, pp. 48-49.
} 
Por temer a avaliação pública e por saber que estas ocasiões serviam sempre para angariar novos irmãos e sobretudo novos legados, as Misericórdias faziam questão de promover cerimónias grandiosas, principalmente quando se tratava do enterro dos irmãos, fazendo «despedidas triunfais». ${ }^{9}$ Constituíam encenações cuidadas e muito apreciadas. Proporcionava-se uma festa fúnebre num acto de homenagem ao falecido, mas ao mesmo tempo procurava-se captar novos irmãos e benfeitores.

A morte dava lugar a uma ocasião festiva, criando um espectáculo repetido com frequência. ${ }^{10}$ Ao mesmo tempo que se experimentava o carácter provisório da vida, mantinha-se acesa a esperança na salvação. ${ }^{11}$

$\mathrm{O}$ róis dos bens existentes na sacristia da Misericórdia de Ponte de Lima (Norte de Portugal) da primeira metade do século XVIII demonstram bem o investimento da Santa Casa para se apetrechar com o que de melhor existia, sabendo que muitos destes bens e objectos não apenas testemunhavam a grandeza dentro da sua igreja, como eram usados em manifestações públicas de rua. A confraria comprava o que considerava ser melhor para a sua representação e reforço do seu prestígio (cfr. Anexo 1).

Os paramentos existentes na sacristia eram verdes, vermelhos, roxos e brancos. Todavia, as cores branca, azul, rosada e preta também existiam. A paleta cromática era muito variada, alegre e chamativa, bem ao gosto do barroco. Feitos de damasco, de damasquilho, tafetã, de lã e de felepequim, os paramentos eram comprados no reino ou mandavam-se vir do Oriente, como várias vezes aconteceu nesta confraria.

As relações com outras Santas Casas do Estado da Índia, normalmente, por causa do cumprimento de legados, facilitavam, estreitavam relações e ocasionavam a encomenda de panos muito apreciados na Europa de então e que o gosto barroco tinha em moda. ${ }^{12}$ Os cálices de prata, os objectos de estanho e de ferro possibilitam apreciar mais alguma da riqueza de uma Misericórdia de média dimensão.

9 A expressão é utilizada por Ana Cristina Araújo, para designar funerais grandiosos no século XVIII. Confira-se A. C. ARAúJo, «Despedidas triunfais - celebração da morte e cultos de memória no século XVIII», in I. Jancsó, I. Kantor, (org.), Festa. Cultura e Sociabilidade na América Portuguesa, vol. I, São Paulo, Imprensa Oficial, 2001, pp. 17-33.

${ }^{10}$ No Antigo Regime, a taxa de mortalidade era muito elevada.

11 A. C. ARAúJo, «Morte, memória e piedade barroca», in Revista de História das Ideias, vol. II, 1989, pp. 130, 141.

12 Sobre a riqueza dos paramentos da Sé de Braga no século XVIII confira-se N. M. FerReIRA ALVES, «Nótulas para o estudo da paramentaria bracarense no século XVIII», in Revista da Faculdade de Letras, II série, vol. VIII, 1991, pp. 307-317. 
Estes róis eram elaborados anualmente, sendo possível constatar ainda a existência de objectos de ouro: cálices, custódias e resplendores. O brilho dos metais preciosos associava-se às cores dos paramentos, conferindo aos desfiles em que a irmandade participava aparato, magnificência a grandeza.

A aquisição destes bens e a opulência que algumas Misericórdias apresentavam desde a segunda metade do século XVII deveu-se à chegada de legados. Como a historiografia mais recente tem demonstrado, as Santas Casas conheceram na segunda metade desse século o maior caudal de legados, ${ }^{13}$ permitindolhes manifestações pomposas, festas grandiosas e afirmação do seu poder.

\section{OS PEDITÓRIOS}

Uma das formas que as Santas Casas tinham para garantir receitas foi o recurso a peditórios. Na realização dos peditórios, os irmãos tinham novamente que sair de casa para em nome da instituição pedir para as obras de caridade. Faziam-no duas vezes por semana: às quartas e aos domingos, sempre que a Mesa se reunia, nas ocasiões festivas e depois, normalmente na época das colheitas, quando iam pedir pelas eiras e lagares.

Os peditórios semanais eram da responsabilidade da Mesa. O provedor formava equipas de dois mesários (um nobre e outro oficial), onde ele próprio se integrava, e distribuía as ruas onde cada equipa actuava. Os mesários saíam com os seus balandraus e empunhavam varas para que rapidamente fossem identificados e merecessem a atenção das populações. Nobres e oficiais pediam para os pobres, encenado uma situação em que os ricos se faziam pobres. Não era um espectáculo menor ver sair e caminhar pelas ruas duas vezes por semana o órgão de gestão da confraria mais importante da terra. Muitos destes homens eram cavaleiros de Sua Majestade e fidalgos da Casa Real. Nobres da alta estirpe, que, tal como os pobres, rogavam em nome de Nossa Senhora da Misericórdia.

Mas o grande peditório destas instituições fazia-se no tempo das colheitas. Quando o Verão estava a terminar e se iniciava o Outono, os confrades saíam uma vez mais à rua com os seus balandraus e varas para pedir. Faziam-no numa

13 Vejam-se os trabalhos de L. Abreu, A Santa Casa da Misericórdia de Setúbal de 1500 a 1755 : aspectos de sociabilidade e poder, Setúbal, Santa Casa da Misericórdia de Setúbal, 1990, pp. 47-49; M. D. Sousa PereIra, Entre ricos e pobres..., p. 98; A. J. R. Rusell-Wood, Fidalgos e Filantropos. A Santa Casa da Misericórdia da Bahia 1550-1755, Brasília, Editora Universidade de Brasília, 1981, pp. 121-122; M. OliveIra BARreIRA, Santa Casa da Misericórdia de Aveiro: poder, pobreza e solidariedade, Aveiro, Santa Casa da Misericórdia de Aveiro, 1998, p. 92; M. M. Lobo DE Araúso, Dar aos pobres e emprestar a Deus: as Misericórdias de Vila Viçosa e Ponte de Lima (séculos XVI-XVIII), Barcelos, Santa Casa da Misericórdia de Vila Viçosa; Santa Casa da Misericórdia de Ponte de Lima, 2000, pp. 141-142, 463-464. 
área alargada, nas freguesias em que estavam autorizados a angariar esmolas. Neste acto não actuava apenas a Mesa, mas os confrades que fossem necessários. Nos lugares mais longínquos serviam-se de mamposteiros, ${ }^{14}$ para realizarem esta tarefa. Estes homens eram normalmente auxiliados por um irmão. Depois de reunidas as esmolas (trigo, milho, azeite e/ou dinheiro), os bens chegavam à Santa Casa trazidos pelos irmãos ou pelos mamposteiros. Era um corrupio de gente que chegava carregada de esmolas à sede da instituição, criando um efeito festivo, mas, simultaneamente, pedagógico, ensinando a dar para ajudar.

\section{AS CERIMÓNIAS DA SEMANA SANTA}

Tempo de arrependimento e da Paixão, a Quaresma constituía todos os anos um momento forte de chamamento dos crentes às igrejas para participarem nas cerimónias religiosas. Os agricultores largavam os trabalhos para se fazerem aos caminhos e acorrer à igreja ou à confraria a que pertenciam, para assistirem às solenidades religiosas. Os dias de missas, orações, sermões e procissões eram muitos, mas obter o perdão dos pecados e rogar pelos vivos e pelos mortos não era responsabilidade menor em tempo de cuidar da alma.

As Misericórdias celebravam empenhadamente esta quadra, promovendo e participando em cerimónias religiosas. Estas decorriam ao longo da Quaresma, mas tornavam-se mais intensas na semana santa.

Esta semana abre-se com o domingo de ramos, dia em que se celebrava a procissão dos Passos. Festa grandiosa, era comemorada no século XVIII em Monção não só com a representação cénica da bíblia, mas também com missa, música, sermão, toque de sinos e fogo-de-artifício. ${ }^{15} \mathrm{~A}$ Santa Casa encomendava a feitura das capelas a um carpinteiro, onde montava os quadros alegóricos que possuía sobre a última fase da vida de Cristo. A estas figuras alegóricas e mitológicas, juntavam-se figuras reais, que também desfilavam na procissão. Como desejava ser considerada pelo povo que assistia, a confraria recomendava aos carpinteiros empenho e esmero e não tolerava «indecencia», porque como diziam os confrades «seriam avaliados». Caírem nas «bocas do mundo», serem falados, era algo que não convinha ao crédito e à honra dos irmãos. Tudo faziam para que nestas ocasiões os seus actos fossem enaltecidos e dignos de uma grande instituição onde militavam os «melhores» da terra.

\footnotetext{
${ }^{14}$ Pedidores autorizados de que as Misericórdias se serviam para rogar esmolas em seu nome em várias freguesias.

${ }^{15}$ A propósito da importância dos fogos de artifício nas festas barrocas veja-se A. P. REBELo CoRREIA, «Fogos de artifício e artifícios de fogo nos séculos XVII e XVIII: a mais efémera das artes efémera», in A arte efémera em Portugal, Lisboa, Fundação Calouste Gulbenkian, 2001, pp. 101-149.

Hispania Sacra, LXII

125, enero-junio 2010, 93-113, ISSN: 0018-215-X
} 
Na Misericórdia de Monção esta era a principal festa. Por isso, começava-se cedo a prepará-la. Em 1789, numa reunião em meados de Janeiro, mandaramse fazer compras e restauros com vista a manter a dignidade da festa. Ordenou-se a compra de «huma tunica para o Senhor dos Passos, que foce de cetim roxo e um deadema novo ou resplendor para a cabeça e mais uma cortina roxa de tafetã para por por dentro da vidraça». Ordenou-se também a aquisição de uma capa nova para a imagem do Senhor da Cana Verde e de um cálice. Os missais foram mandados compor. ${ }^{16}$ No começo de Março do mesmo ano a atenção recaiu na feitura das capelas pelos carpinteiros. ${ }^{17} \mathrm{Ou}$ seja, considerada a grandeza da festa, os irmãos começavam bem cedo a prepará-la, encomendando arte efémera, deixando para as vésperas apenas o que não podia ser feito antes.

A montagem das capelas e a colocação dos quadros e painéis com as figuras alegóricas revestia-se de algum secretismo, de forma a criar um efeito surpresa. Por isso, só podiam ser montadas na véspera.

A capacidade da fascinar e de surpreender estava muito em voga. ${ }^{18} \mathrm{O}$ barroco premiava este efeito, ao apelar às emoções e aos sentimentos.

$\mathrm{Na}$ Santa Casa de Melgaço, a procissão dos Passos tinha ao longo do desfile imagens alegóricas cheias com palha. A confraria comprava o colmo para as encher, tendo gasto 120 mil réis, em $1725 .{ }^{19}$

Nesta cerimónia integravam-se os capelães da Casa, mas era costume serem requisitados outros sacerdotes, criando maior aparato ao momento.

A Misericórdia de Chaves conserva ainda a descrição desta procissão, criando memória para que anualmente a cerimónia se repetisse com dignidade. Simultaneamente, procurava diminuir a razão dos que se desculpavam com desconhecimento da forma como devia decorrer a iniciativa.

\section{PROCISSÃO DOS PASSOS AO CALVÁRIO NA MISERICÓRDIA DE CHAVES}

Irmãos da Meza

O irmão mais moderno de primeira com a matraca

Guião- O irmão escrivão

$1^{\text {a }}$ Vara - O irmão mais antigo da primeira condição

Com caixa que he o provedor das noticias como abaixo declara

\footnotetext{
${ }^{16}$ Arquivo da Santa Casa da Misericórdia de Monção (doravante ASCMM), Livro que ha de servir dos acordons desta Santa Mizericordia da villa de Monçom 1774-1815, n 12 , fl. 82v.

${ }^{17}$ ASCMM, Livro que ha de servir dos acordons..., fl. 84.

${ }^{18}$ Leia-se para este assunto V. TAPIÉ Barroco e Classicismo II, Lisboa, Ed. Presença, 1972, pp. 54-55.

${ }^{19}$ Arquivo da Santa Casa da Misericórdia de Melgaço (doravante ASCMço), Livro de receita e despeza 1717-1749, fl. 117.
} 
$2^{\text {a }}$ Vara- O irmão esmoler com caixa

$3^{\text {a }} \mathrm{O}$ irmão que segue ao primeiro com caixa - escrivão das notas

$4^{\mathrm{a}} \mathrm{O}$ Irmão da segunda condissão que se segue ao esmoler e tezoureiro que he esmoler das noticias, vara e caixa

O provedor das noticias vara e caixa

O escrivão das noticias vara e caixa

O irmão mais moderno das Meza da primeira

Aos anjos com vara e caixa

Os mais irmãos da primeira com vara e quarta de agoa

Os irmãos da segunda com vara e garrafa de vinho

Andor do Senhor da Cruz às costas

Dous escrivaiens e seus esmoleres os mais antigos sendo capazes para o travalho do pezo

Tocheiros a elle

Dous provedores e dous esmoleres proferindo os antigos

Paleo

Os tres provedores e tres esmoleres, preferindo os mais antigos

Tocheiros a ele:

Tres provedores e tres esmoleres e na falta destes preferirão em todas as insignias os escrivães e tesoureiros pela sua antiguidade

O senhor provedor com a vara atrás do palio

Dará cera aos irmãos um irmão de segunda e aos sacerdotes um de primeira

A esmola ao andor do Senhor tirarão dous irmãos de segunda os mais antigos que não hajão sido esmoleres nem tesoureiros

Anjos:

$1^{\circ} \mathrm{O}$ calix

$2^{\circ}$ Coluna e asantes

$3^{\circ}$ A Santa Veronica

$4^{\text {a }}$ Cravos e martelo

$5^{\circ}$ Coroa

$6^{\circ}$ Dados e esponja

$7^{\circ}$ Titulo e lança..$^{20}$

20 Arquivo da Santa casa da Misericórdia de Chaves, Livro dos acórdãos e deliberações 1670$1808, \mathrm{n}^{\circ} 3$, fls. 4-4v. 
O desfile era aberto pelos irmãos da Mesa, mas a procissão envolvia antigos e novos confrades no desempenho de várias funções: desfile com varas, tochas, caixas de esmolas, respeitando lugares, hierarquias e precedências. O lugar mais importante era ocupado pelo provedor, que desfilava com a sua vara atrás do pálio.

As procissões barrocas transformavam-se em momentos de pedagogia e de apelo aos sentimentos. Matracas, cravos, martelos, coroas, esponjas, lanças e andores eram preparados e transportados durante a procissão, apelando à penitência de todos os fiéis.

Apesar do empenho, era na quinta-feira santa que se conjugavam mais cerimónias públicas: o jantar dos presos, o lava-pés e a procissão das Endoenças.

As Misericórdias portuguesas alcançaram desde muito cedo privilégios para ajudar os presos. ${ }^{21}$ Para além de limparem as cadeias, os irmãos auxiliavam os presos, correndo com os seus livramentos, muniam-nos de alimentos todos os domingos e quartas-feiras, socorriam-nos na doença, davam-lhes roupa em caso de necessidade e assistiam-nos espiritualmente e na morte.

Para além destas ajudas, no dia de quinta-feira santa serviam-lhe um jantar, onde não faltavam iguarias e até música, como acontecia em Tavira. ${ }^{22}$

Em Vila Viçosa, terra dos duques de Bragança e sede do seu paço até 1640, data em que partiram para Lisboa para assumir a Coroa, o jantar dos presos transformou-se num momento de grande investimento da Misericórdia. A refeição era preparada na cozinha da confraria, mas a Mesa deslocava-se em procissão até à prisão para dar de comer aos encarcerados. $O$ desfile era aberto por dois serventes da cozinha seguidos do requerente e do porteiro da Casa que caminhavam com os seus chapéus nas mãos. Depois destes seguiam dois irmãos (um nobre e outro oficial) com a louça e a canastra, iam depois outros dois com o pão e a toalha e mais dois com o jantar de carne, num caldeirão de cobre. Os restantes irmãos caminhavam aos pares com outros bens necessários e no fim iam o provedor e o capelão com dois frascos de prata com vinho. Todos os confrades caminhavam com os seus balandraus e o capelão envergava a sobrepeliz. ${ }^{23}$

Mantidas as hierarquias e as precedências, os confrades saíam do centro da vila onde estavam instalados, eram presenciados por todos os que desejassem assistir, e dirigiam-se para a cadeia. $\mathrm{O}$ jantar era servido sempre com muita

\footnotetext{
${ }^{21}$ Sobre este assunto leia-se I. CARneIRo DE SousA, V Centenário das Misericórdias Portuguesas, Lisboa, CTT, 1998, p. 71.

${ }^{22}$ A. Casimiro Anica, O hospital do Espírito Santo e a Santa Casa da Misericórdia da cidade de Tavira (da fundação à actualidade - notas), Tavira, s. e., 1983, p. 50.

23 Arquivo da Santa casa da Misericórdia de Vila Viçosa, (doravante ASCMVV), Livro de Lembranças, $\mathrm{n}^{\circ} 92, \mathrm{fl} .140$.
} 
abundância, registando-se anos em que lhes ficava comida para o resto da semana, e, não raras vezes, era servido com talheres de prata. Estes objectos de luxo, que só uma sociedade apostada na grandeza e no espectáculo patrocinava, foram por vezes oferecidos pelo provedor aos detidos. Testemunhavam a magnanimidade, a riqueza e a ostentação, mas também o desprendimento do provedor e a sua compaixão para com os que eram pobres e estavam presos.

O barroco patrocinava estes momentos de exuberância e simultaneamente de despojamento.

Já a cerimónia do lava-pés desenrolava-se dentro da igreja, mas era também um momento espectacular. Reproduzindo a cena bíblica em que Cristo lavou os pés aos 12 apóstolos, o provedor lavava os pés a igual número de pobres. $\mathrm{O}$ cerimonial acontecia no espaço sagrado, mas mesmo assim dava lugar a um pequeno cortejo.

Em Vila Viçosa, o requerente e o porteiro abriam-no, seguindo-se os 12 pobres «descarapuçados» com os pés descalços e aos pares. Os mesários desfilavam também dois a dois e com os seus balandraus. $\mathrm{O}$ provedor seguia com o seu balandrau e depois dele vinham ainda outros irmãos com uma estante e o missal para se cantar o Evangelho, outros com tolhas e uma bacia de latão com água quente, um gomil e um prato para aparar a água. Os pés eram lavados pelo provedor, que simulava um gesto de humildade, dado como exemplo a todos os presentes. ${ }^{24}$

Este ritual invertia as hierarquias sociais e mesmo políticas, uma vez que reis e duques lavavam os pés a pobres, assim como o papa os lavava aos seus cardeais..$^{25}$

Era ainda neste dia que as Misericórdias realizavam a principal saída processional. Só por esta razão, mas também porque se tratava de um dos dias mais importante do calendário litúrgico, a cerimónia era preparada atempadamente e o compromisso da Misericórdia de Lisboa ordenava a presença da instituição em corpo. No dia seguinte, as Santas Casas voltavam a desfilar, mas o cortejo não atingia o esplendor do da quinta-feira. Todavia, na Misericórdia de Chaves, a cerimónia exigia preparativos atempados. Um acórdão de 1740 dava conta do percurso que esta procissão efectuava, dos paramentos usados e dos figurantes que a deviam integrar. ${ }^{26}$

Considerada a força representativa destes momentos, as instituições em causa mobilizavam todos os esforços para que as realizações fossem admiradas e

\footnotetext{
${ }^{24}$ ASCMVV, Livro de Lembranças, ${ }^{\circ}$ 92, fl. 139.

${ }^{25}$ A propósito dos rituais confira-se E. MUIR, Fiesta y rito en la Europa Moderna, Madrid, Editorial Complutense, 2001, p. 70.

${ }^{26}$ ASCMC, Livro dos acórdãos e deliberações 1670-1808, n 3, fls. 68-72v. 
louvadas. Distribuíam-se as tarefas com antecedência e recordava-se aos responsáveis a obrigação de vigiar para que tudo decorresse como tinha sido pensado. Exigia-se que os paramentos estivessem asseados e engomados, se comprassem paramentos novos, em caso de necessidade, mandavam-se restaurar os cálices, as alvas e as sobrepelizes, as lanternas e outros objectos, aprontavam-se as hóstias e davam-se ordens à lavadeira para tratar de toda a roupa da sacristia: sanguinhos, amitos, corporais e outros panos eram lavados e passados. Mas as cortinas e os para-ventos eram igualmente vistoriados. Ordenava-se a compra da cera, dos novelos e das lanternas, preparavam-se as bandeiras, as varas, o guião e montavam-se os andores. Mandavam-se ainda fazer os mantos para os santos e, quando necessário, comprava-se a cabeleira para o Senhor da Cana Verde. Adquiria-se o incenso e mudava-se a água baptismal, para ser posteriormente aspergida sobre o povo. As preocupações com a igreja eram muitas, por nela se concentrarem todos os olhares.

$\mathrm{O}$ arranjo da igreja era também considerado. As flores eram pensadas e adquiridas para o momento e recorria-se a um sistema de embelezamento do espaço sagrado.

A decoração das igrejas obedecia ao estipulado nas Constituições Sinodais e devia ajustar-se à celebração do calendário litúrgico. Nas Constituições Sinodais de Braga de finais do século XVII ordenava-se que

«[...] Os retabolos das Igrejas terão cortinas com que se cubrão, brancas ou vermelhas [...] para a Quaresma terão pannos pretos com passos da sagrada Paixão, ou cruzes pintadas: e sobre os Altares averá sobreceos de seda, ou de linho com suas sanefas, e franjas ao redor: sobre o Sacrario do Santissimo Sacramento haverá hum pavelhão de seda vermelha, todo franjado, com seu capello: e para a Quaresma, e Advento outro de seda roxa»..$^{27}$

Em tempos barrocos adoptou-se o gosto por revestir as igrejas com panos de seda de várias cores, aumentando o ar de festa. As igrejas davam lugar a locais de encenação e de teatro, tanto ao gosto da época.

As melhorias feitas na igreja, nos paramentos e na sacristia, bem como, toda a encenação montada, destinava-se a apresentar uma Igreja forte, unificadora e arrebatadora. Estes processos eram eficazes na mensagem que se queria passar de forma fácil aos fiéis. ${ }^{28} \mathrm{~A}$ arquitectura associava-se à pintura, à escultura, ao

\footnotetext{
${ }_{27}$ Constituiçoens Sinodais do arcebispado de Braga ordenadas no anno de 1639 pelo Illustrissimo Senhor Arcebispo D. Sebastião de Matos Noronha E mandadas imprimir a primeira vez pelo Illustrissimo Senhor D. João de Sousa arcebispo e senhor de Braga, Primaz das Espanhas do Conselho de sua magestade e seu sumiller da cortina, Lisboa, Officina de Miguel Deslandes, 1697, p. 332.

${ }^{28}$ Confira-se F. ENES, «As confrarias do Santíssimo Sacramento e das Almas no âmbito da cultura barroca (um caso na diocese de Angra)», in I Congresso Internacional do Barroco - Actas, vol. I, Porto, Reitoria da Universidade do Porto; Governo Civil do Porto, 1991, p. 283.
} 
azulejo, à paramentaria, à talha dourada, à luz, aos gestos do celebrante e à música, criando um efeito arrebatador, onde primava a emoção, o luxo e a ostentação. Estes factores concorriam para que as manifestações de exterior se enchessem de colorido e pompa ${ }^{29}$ e contrariassem um quotidiano marcado por privações, medo e insegurança.

Luxo e conforto, adquiridos através da acumulação dos melhores objectos, criam a ilusão de que toda a riqueza está ao dispor dos crentes ${ }^{30} \mathrm{~A}$ cultura da aparência fazia crer na disponibilidade e possibilitava a construção de imaginários onde se davam largas às sensibilidades, aos gostos e às originalidades.

À encenação da igreja juntavam-se a palavra e os gestos do celebrante. «A colocação das mãos, a direcção dos olhos, o estar reverentemente de pé, ou de joelhos num gesto de prece eram atitudes corporais que se desenvolviam em unanimidade, exprimindo uma atitude interior vivida por todos»,,$^{31}$ e sublinhavam a expressão dramática da festa barroca.

Determinava-se ainda que os irmãos aparecessem compostos, ou seja, com os seus balandraus e exigia-se-lhes pontualidade e decência enquanto estivessem fora de portas.

O percurso era definido com minúcia, de forma a integrar as principais igrejas da terra e a desenrolar-se passando à porta dos mais ilustres. No Porto, o itinerário integrava algumas das igrejas da cidade, valorizando o centro urbano. ${ }^{32}$

Davam-se ordens para preparar o caminho, limpar os muros, alisar e compor o terreno. Era necessário contratar homens para «fazer o caminho», isto é, preparar o trajecto do desfile. A rua transformava-se no palco onde ocorria a representação e as fachadas dos prédios no cenário decorativo. ${ }^{33}$ As colchas e as tapeçarias nas varandas compunham o aparato festivo.

Mas a Casa era também tida em consideração: pintava-se a frontaria, caiavase o quintal e em alguns anos compunha-se o telhado. Tudo para criar uma imagem de riqueza, aparato e eficiência.

\footnotetext{
${ }^{29}$ Sobre as festas das confrarias em Minas Gerais veja-se C. CÉsAR Boschi, Os leigos e o poder. (Irmandades leigas e política colonizadora em Minas Gerais), São Paulo, Editora Ática, 1986, p. 58.

${ }^{30}$ Leia-se R. Muchembled, L'invention de l'homme moderne. Sensibilités, moeurs et comportements collectifs sous l'Ancien Régime, Paris, Fayard, 1988, p. 375.

${ }^{31}$ Consulte-se para este assunto M. M. M. CAMPOS, Braga. A cidade e a festa no século XVIII, Braga, NEPS, 2003, p. 337.

32 Veja-se I. CARNEIRO DE SousA, «A procissão de quinta-feira Santa da confraria da Misericórdia do Porto», in $O$ Tripeiro, $7^{\text {a }}$ série, ano XIV, ${ }^{\circ} 4,1995$, p. 113. Em Elvas, a procissão percorria todas as igrejas da vila. Leia-se E. GAmA, A Santa Casa da Misericórdia de Elvas, Coimbra, Santa Casa da Misericórdia de Elvas, 1954, p. 123.

${ }^{33}$ A simbologia das ruas e das casas encontra-se em J. M. TEDIM, «A procissão das procissões. A festa do Corpo de Deus», in A arte efémera em Portugal..., p. 218.
} 
A música era escolhida com critério e adequada ao momento. Quando na terra não existiam bons coros e instrumentistas, pagava-se o serviço a homens que vinham de fora. A música estava sempre presente em todas as festas das Misericórdias. Nas instituições de maior dimensão, existia um mestre de capela, mas para as festas contratava-se um organista e outros músicos considerados necessários para o momento.

Também os religiosos que proferiam os sermões eram criteriosamente seleccionados. Normalmente, as Misericórdias recorriam às ordens religiosas existentes na localidade a quem encomendavam os sermões. Mas escolhiam o homem que queiram ver no púlpito.

A pregação era um dos momentos mais importantes. O pregador devia ser destro na oratória, escolher as palavras certas para impressionar e persuadir. «Médico de almas», os pregadores recorriam com frequência a metáforas para impressionar e, de forma mais eficaz, aplicar o «remédio» aos «doentes». ${ }^{34}$

Os gastos com estas cerimónias eram muitos, mas quase nunca se mandou poupar ou se emitiram recados no sentido de se diminuir o brilho que causava encanto. Bem pelo contrário, durante os séculos XVII e XVIII assistiu-se a um investimento crescente nas festas religiosas e nos momentos em que estas confrarias se manifestavam no exterior.

\section{AS PROCISSÕES}

Para a procissão de quinta-feira das Endoenças era ainda necessário chamar os penitentes. Este desfile, bem como o do domingo de Passos ${ }^{35}$ integravam flagelantes.

A integração de pessoas que se iam flagelando ao longo da procissão, simbolizando o martírio, era aplaudida pela igreja tridentina. Procurava-se redimir os pecados desta forma e reviver de maneira directa a dor de Cristo. A flagelação foi corrente neste período e tanto podia ocorrer na intimidade das celas, como nos púlpitos e ser presenciada pelos crentes. Martirizar o corpo para salvar a alma era proclamado pelos agentes da igreja católica, com o objectivo de demonstrar a superioridade do espírito em relação ao corpo.

O espectáculo proporcionava não só efeitos visuais, como objectivava a reprodução dos actos. O som das matracas ouvia-se a uma distância considerável,

${ }^{34}$ Leia-se M. Massimi, Palavras, almas e corpos no Brasil colonial, São Paulo, Edições Loyola, $2005,235$.

${ }^{35}$ A referência a penitentes na procissão dos Passos é conhecida para algumas Misericórdias. Vejase para Melgaço ASCMMço, Livro de receita e despeza 1717-1749, fl. 47. 
recordando a todos os presentes e ausentes a necessidade de se penitenciarem perante os pecados cometidos. Na descrição que o cronista João Baptista de Castro fez, em meados do século XVIII, da procissão da Santa Casa de Lisboa, referiu $^{36}$ as largas centenas de homens e mulheres que se flagelavam neste desfile.

Depois de terminar a procissão, as feridas dos penitentes eram tratadas com vinho e/ou vinagre e estes recebiam uma pequena refeição. ${ }^{37}$

A integração de flagelantes conferia relevo à importância dada por estas confrarias à espiritualidade da Paixão.

As procissões adquiriram por todo o lado um efeito cénico de relevo e eram marcadas pelo apelo à sensibilidade.

Estes acontecimentos concorriam para engrandecer a fé e as práticas religiosas dos irmãos e devem ser entendidos como manifestações de «comunicação inseparável entre assistência e caridade, auxílio e penitência». ${ }^{38}$

Esta procissão iniciava-se ao final da tarde e terminava pela noite dentro. No Porto, a procissão de quinta-feira das Endoenças começava pelas cinco horas da tarde, mas é sabido que em outras localidades tinha início um pouco mais tarde.

$\mathrm{Na}$ Misericórdia desta cidade, o cortejo era aberto com a bandeira da irmandade, transportada por um irmão nobre e ladeada por dois confrades com tochas acesas. Esta era seguida por dois capelães que cantavam a ladainha. Doze insígnias com a Paixão de Cristo eram levadas por igual número de irmãos, seis nobres e seis oficiais, indo em cada ilharga de cada insígnia dois irmãos com tochas acesas. Mais dois capelães acompanhavam este segundo quadro cantando a ladainha.

Os penitentes davam corpo ao desfile, mas os crentes que não o integravam contribuíam para que este se tornasse grandioso.

Todos os irmãos que não ocupassem nenhum cargo na procissão, desfilavam com círios acesos nas mãos.

No final do cortejo ia a imagem do Cristo coroado de espinhos e à sua frente os capelães cantando a ladainha. Seguia-se o escrivão e mais doze irmãos e

\footnotetext{
${ }^{36}$ Esta descrição pode ler-se em J. Verissímo SerRÃo, A Misericórdia de Lisboa. Quinhentos anos de História, Lisboa, Livros Horizonte, 1998, p. 200.

${ }^{37}$ Em Esposende serviam-lhes marmelada, confeitos e doces. Veja-se M. M. Costa DA Silva, A Misericórdia de Esposende e a semana santa, s. 1., Santa Casa da Misericórdia de Esposende, 1988, pp. 34-35. Em algumas confrarias espanholas alguns irmãos distribuíam-lhes água e comida durante a procissão, enquanto outros tratavam de providenciar unguentos e outros tratamentos para as feridas. Veja-se M. P. CARroll, The penitent brotherhood. Patriarchy and Hispano-Catholicism in New Mexico, Baltimore and London, The Johns Hopkins University Press, 2004, p. 168.

38 Confira-se I. CARNEIRO DE SOuSA, «Da fundação e da originalidade das Misericórdias portuguesas (1498-1500)», in Oceanos, n 35,1998 , p. 30.
} 
só depois vinha o provedor com a sua vara na mão, acompanhado pelos restantes mesários. Todos empunhavam tochas acesas. O cortejo era encerrado pela imagem de Cristo morto, ladeado por dois irmãos com tochas acesas.

Ao longo de toda a procissão caminhavam 12 irmãos com as suas varas na mão. Iam a «governar» o desfile, ou seja, a colocarem ordem e a fazerem com que esta se mantivesse. Estes desfiles nem sempre estavam imunes a desacatos e a distúrbios. ${ }^{39}$

Para que não faltasse luz, em certos lugares do itinerário eram acesos fogaréus. O cortejo saía da Santa Casa, passava pela Sé e pelas igrejas de S. Francisco e de $\mathrm{S}$. Domingos e regressava à Santa Casa. ${ }^{40}$

Terminava já de noite. Aliás, algumas destas confrarias estendiam esta realização até para além da meia-noite.

Por fim, a «procissão dos ossos». No dia de Todos-os-Santos, as Misericórdias realizavam uma procissão à forca para levantar e enterrar os ossos dos que padeciam por justiça. Por se tratar dos mais desprotegidos, os irmãos tinham a obrigação estatutária de permanecer a esta cerimónia com os seus balandraus. Era uma demonstração de empenho e de solidariedade, colocando-se ao lado dos que padeciam, penando. Depois de recolhidas, as ossadas eram colocadas numa tumba e transportadas até ao local de enterramento. Seguia-se uma missa pela alma dos padecentes.

Mesmo que não houvesse ossos para recolher, algumas Santas Casas mantinham viva a tradição da peregrinação e faziam-na anualmente, ${ }^{41}$ cumprindo o ritual.

A realização das grandes manifestações, quer fossem festivas ou não, proporcionava momentos de sociabilidade, de reforço de identidade ${ }^{42}$ e mesmo de promoção de memória colectiva. ${ }^{43}$

\footnotetext{
${ }^{39} \mathrm{Na}$ Misericórdia de Castelo Branco ia um irmão com a função de «aquietar o tumulto que costuma haver». Consulte-se CASTRO e H. SILVA, A Misericórdia de Castelo Branco (apontamentos históricos), Castelo Branco, s. e., 1958, p. 110.

${ }^{40}$ A descrição da procissão encontra-se em E. A. Cunha Freitas, História da Santa Casa da Misericórdia do Porto, vol. III, Porto, Santa Casa da Misericórdia do Porto, 1995, pp. 194-196.

${ }^{41}$ Veja-se M. M. Lobo de ARAúuo, Dar aos pobres e emprestar a Deus..., pp. 679-680.

${ }^{42}$ C. CÉsAR BosChI, «Sociabilidade religiosa laica: as irmandades», in F. BETHENCOURT, K. CHAUDHURI, História da Expansão Portuguesa, volume 3, Lisboa, Círculo de Leitores, 1998, pp. 360-361.

${ }^{43}$ Segundo Stuart Schwartz as manifestações festivas realizadas na Bahia durante a Idade Moderna serviam para promover a memória histórica colectiva, reforçando também desta forma a pertença ao império. Veja-se S. SCHWARTZ, «Ceremonies of public authority in a colonial capital. The king's processions and the hierarchies of power in seventeenth century Salvador», in Anais de história de alémmar, V, 2004, p. 13.
} 
Mas a presença das Misericórdias em procissões não se confinava aos desfiles que promoviam. Participavam também em cortejos processionais realizados por outras confrarias, ordens religiosas, sés, mitras e cabidos.

Marcavam presença assídua na procissão de quarta-feira de Cinzas, acto promovido pelas Ordens Terceiras e iam também sempre que eram chamadas em procissões que se faziam para rogar mudança de tempo. ${ }^{44}$

Estas realizações, que apelavam à perenidade da vida, agregavam muita gente e transformaram-se ao longo do século XVIII na maior manifestação religiosa das Ordens Terceiras. ${ }^{45}$

Integravam também a procissão do Corpus Christi e outras manifestações religiosas locais.

Nas procissões, a disposição das confrarias obedecia a um esquema previamente pensado que respeitava as precedências. As Santas Casas participavam nestes actos, mas eram muito ciosas do seu lugar, não o dispensando em caso algum. O estabelecimento de precedências nas procissões expressa a hierarquia social e corporiza o lugar que cada um ocupava na ordem estabelecida. ${ }^{46}$

\section{SER VISTO A DAR}

Outros momentos de exposição ficaram marcados pela distribuição de esmolas. Todas as quartas e domingos, depois da celebração da missa, eram entregues esmolas aos pobres do «rol da porta». ${ }^{47}$ Os mesários encarregavam-se de distribuir, no pátio da Casa, as esmolas, normalmente em pão e dinheiro. Com excepção dos presos e entrevados, todos os restantes deviam assistir à missa e esperar no pátio que os mesários chegassem para lhes entregar as esmolas.

Estes momentos em que as Misericórdias se abriam de forma directa ao exterior, possibilitavam contactos entre os confrades e uma «clientela» de pobres já conhecida das instituições.

${ }^{44}$ A Misericórdia de Braga manteve uma presença mais ou menos regular nestas realizações. Vejase M. F. CAstro, A Misericórdia de Braga, Braga, Santa Casa da Misericórdia de Braga e Autora, 2003 , p. 416.

45 Estas procissões eram feitas em todas as Ordens Terceiras. Leia-se A. ArAnTEs CAMPOs, «As Ordens Terceiras de São Francisco nas Minas coloniais: cultura artística e procissão de Cinzas», in Estudos de História, França, vol. 6, n 2, 1999, p. 125.

46 Para este assunto confira-se S. SCHWARTZ « Ceremonies of public authority in a colonial capital...», p. 18.

${ }^{47}$ Lista de providos todas as quartas e domingos. 
O que se passava no pátio podia em quase todas as Misericórdias (sempre situadas no cento das vilas e cidades) ser presenciado pelos transeuntes, conferindo momentos em que os irmãos eram vistos a dar.

Nos séculos XVII e XVIII, as Misericórdias transformaram-se em instituições barrocas e passaram a distribuir esmolas a um grande número de pobres na quinta-feira santa, no dia de Fiéis-Defuntos e no Natal. ${ }^{48}$ A entrega dava lugar a um espectáculo grandioso de desprendimento e auxílio aos mais pobres. Estas manifestações festivas que decorriam ao longo do ano, marcavam tempos importantes do calendário litúrgico e destinavam-se a ser observadas. Sempre às centenas ou aos milhares, os pobres aguardavam pela sua vez para serem contemplados com a esmola.

Estas cerimónias conferiam visibilidade aos irmãos e engrandeciam-nos em termos pessoais e institucionais. Reforçavam a própria identidade e capitalizavam autoridade em termos locais.

Movidos por pressupostos que assentavam na piedade cristã, os confrades procediam a estes festivais de caridade, legitimando publicamente o seu poder, ao mesmo tempo que engrandeciam a credibilidade institucional.

\section{CONCLUSÃO}

O poder das Misericórdias expressava-se nestas manifestações de rua, tornando-as instrumentos importantes do seu prestígio. Eram tanto mais engrandecedores quanto elas os conseguiam controlar e os faziam decorrer segundo as suas vontades. As saídas públicas fossem ao pátio, à Sé, a outras igrejas, a mosteiros, às aldeias ou a casas dos pobres contribuíam para fortalecer as relações com o exterior e confirmar a política institucional em curso. Destinavam-se a publicitar e legitimar as suas práticas de caridade, fossem em favor da alma ou em torno do corpo, ao mesmo tempo que reforçavam a sua identidade e conferiam maior sentimento de pertença aos seus membros.

Conhecedoras da importância destes momentos, as Misericórdias tudo faziam para prender a admiração dos crentes. Por esta razão, aproveitavam as ocasiões de associação que promoviam ou em que participavam para afirmar o seu poder, demonstrar riqueza, capacidade organizadora e criar motivos de admiração, deslumbramento e espectacularidade, espelho dos contextos mental, social, cultural e político em que estavam inseridas.

\footnotetext{
$48 \mathrm{O}$ calendário de distribuição podia alargar-se a outros dias.
} 
ANEXO 1

\section{Rol da fabrica da sacristia da Misericórdia de Ponte de Lima, 1718}

Duas campainhas grandes e um apequena

Um coberta do sacrario vermelha e preta

Um ornato da China de dalmaticas e vestimentas, tres frontais de pano de estante branca e pequeno e uma bolsa de corporais da mesma fabrica

Um ornato de damasco roxo vestimentas e um pano de estante grande e pequeno e capa de asperge, seis veos roxos em bom uso e tres ja uzados

Veo de ombros tres vestimentas tres frontais com duas bolsas de chamalote de lam roxa

Uma vestimenta de damasco vermelho com sua bolsa e veo da mesma cor sua bolsa e vei da mesma cor

Uma vestimenta de damasquilho branco com sanefas de veludo roco

Uma vestimenta de felepequim branco

Tres vestimentas e tres frontais de felepequim vermelho

Tres calices dourados com suas patenas

Um veo de ombros de damasquilho vermelho e amarelo

Dois veos brancos que servem um no ornamento da China

Duas cortinas do sacrario

Um pano de tela branco do sacrario

Tres mosqueadores de tafetã com encaixes de prata

Tres frontais e tres veos de tafetã listado

Tres frontais brancos de felepequim

Tres vestimentas da mesma cor com suas bolsas

Tres vestimentas de damasco brancas com bolsas e dalmaticas

Tres vestimentas de felepequim roxo com tres frontais e bolsas

Tres vestimentas de felepequim verde com tres frontais e bolsas

Dez toalhas do altar mor, sete de renda e tres para a mesa da armação

Treze toalhas dos altares colaterais

Quinze capas

Vinte e dois amitos

Vinte alvas, tres das festas

Treze cordoens

Quatro toalhas das maons

Tres sobrepelizes estando uma em cima

Doze toalhas do lavatorio

Um livro de Eusebio

Tres livros do quintal, cinco missais romanos e um bracarense

Tres cadernos

Tres veos brancos de tafetã de Granada 
Nove castiçais de prata

Tres pares de galhetas de estanho com seus pratos

Tres cortinas azuis dos altares

Tres estantes e uma grande das missas solenes

Dois lampadarios de prata

Tres pedras de ara

Um vaso de prata do sacrario e outro pequeno de prata

Um vaso de estanho do lavatorio da comunhão

Um veo branco da custódia

Tres barretes

Tres colheres dos calices

Um veo com sua trena [sic] que serve no vaso do sacrario

Quatro castiçais de ferro com aparadeiras de pau

Tres veos de tafetã branco

Tres veos verdes

Tres veos vermelhos

Umas cortinas pretas do oratorio e outras de tafetã rosado

Uma colcha e nove brancais. ${ }^{49}$

${ }^{49}$ Arquivo da Santa Casa da Misericórdia de Ponte de Lima, Livro de receita e despeza 1718-1719, $\mathrm{n}^{\circ} 520$, não paginado. 